\author{
Shynkaruk Vasyl \\ Doctor of Sciences (Philology), Professor, \\ Dean of the Faculty of Humanities \\ and Pedagogy, \\ National University of Life \\ and Environmental Sciences of Ukraine, \\ ORCID 0000-0001-8589-4995 \\ pedagogy_dean@nubip.edu.ua \\ Salata Halyna \\ PhD in History, Director of the College of \\ Kiev University of Culture \\ ORCID 0000-0002-2673-8463 \\ salaty@bigmir.net \\ Danylova Tetyana \\ PhD in Philosophy, Associate Professor \\ of the Department of Philosophy of the \\ National University of Life and \\ Environmental Sciences of Ukraine \\ ORCID0000-0002-0297-9473 \\ danilova_tv@ukr.net
}

\title{
MYTH AS A PHENOMENON OF CULTURE
}

The purpose of the study. This paper aims at exploring myth as a phenomenon of culture. Methodology of the study. The authors have used anthropological integrative approach, semiotic method of representing myth as a language of culture, as well as phenomenological method. The scientific novelty. Myths provide meaning and purpose to all elements of culture. Myth underlies cultural reality - it is a core of culture. If we imagine culture as an onion comprised of different layers (the "onion" model of culture), then myth is the center of it - it is a core beyond articulation. It generates our beliefs and assumptions that are rarely explicated, however these beliefs and assumptions shape both the structure of personality and culture. They are taken for granted, but support any culture. They manifest themselves in an explicit form in values, purposes, goals, strategies and philosophies, which motivate us and shape our reality. Conclusions. Mythology is one of the ways to comprehend and interpret the world around us. Its basic concepts are the "world" and "human". Through the lens of these concepts, people realized their destiny in the world and formed life attitudes during the early stages of human development. Giving place to philosophy and science, mythology has not lost its important place in human history. Mythological narratives were borrowed by many religions. In recent decades, representatives of literature and art have intentionally used myths to express their ideas. They have not only rethought ancient myths, but have created new mythological symbols. Nowadays, an interest in myths and mythologies has dramatically increased, and it is not by chance. The famous researchers of the primitive cultures and mythologies as the ways of mastering and interpreting the world have demonstrated the creative power and heuristic potential of myths that will be manifested in the future.

Keywords: myth; mythology; worldview; human; world; nature; sacred time; profane time; philosophy; science.

Шинкарук Василь Дмитрович, доктор фрілологічних наук, профресор, декан гуманітарнопедагогічного фракультету Національного університету біоресурсів і природокористування України; Салата Галина Володимирівна, кандидат історичних наук, директор коледжу Київського університету культури; Данилова Тетяна Вікторівна, кандидат фрілософських наук, доцент кафедри фрілософії Національного університету біоресурсів і природокористування України

\section{Міф як феномен культури}

Мета дослідження. Стаття спрямована на дослідження міфу як феномена культури. Методологія дослідження. Автори використовували антропологічний інтегративний підхід, семіотичний метод репрезентації міфу як мови культури, а також френоменологічний метод. Наукова новизна. Міфи надають сенс і мету всім елементам культури. Міф лежить в основі культурної реальності - він є ядром культури. Якщо уявляти культуру як цибулину, що складається з різних шарів (the "onion" model of culture), то міф є її центром - це серцевина, яка $є$ поза артикуляцією. Міф породжує наші переконання та припущення, які рідко виявляються, проте саме вони формують як структуру нашої особистості, так і культуру. Вони вважаються само собою зрозумілими і підтримують будь-яку культуру. Вони проявляються у явному вигляді у цінностях, цілях, стратегіях, філософріях, які мотивують нас і фрормують нашу реальність. Висновки. Міфологія $€$ одним із способів осмислення та інтерпретації навколишнього світу. Ї̈̈ основними поняттями є «світ» і «людина». За допомогою цих понять люди усвідомлювали своє призначення в світі та формували життєві установки на ранніх етапах людського розвитку. Поступившись місцем фрілософії та науці, міфологія не втратила свого важливого місця в людській історії. Міфологічні наративи були запозичені й багатьма релігіями. Останніми десятиліттями представники літератури та мистецтва усвідомлено використовують міфи для вираження своїх ідей. У своїх творах вони не тільки переосмислюють давні міфи, але і створюють нові міфологічні символи. У наш час інтерес до міфу зростає, і навряд чи це випадково. Славетні дос-

(C) Shynkaruk V., 2018

(C) Salata H., 2018

(C) Danylova T., 2018 
лідники первісної культури і міфології як способу освоєння та інтерпретації світу демонструють творчу силу й евристичний потенціал міфу, які проявлятимуться у майбутньому.

Ключові слова: міф; міфологія; світогляд; людина; світ; природа; сакральний час; профанний час; фрілософрія; наука.

Шинкарук Василий Дмитриевич, доктор фрилологических наук, профрессор, декан гуманитарнопедагогического фракультета Национального университета биоресурсов и природопользования Украины; Салата Галина Владимировна, кандидат исторических наук, директор колледжа Киевского университета культуры; Данилова Татьяна Викторовна, кандидат философрских наук, доцент кафедры философии Национального университета биоресурсов и природопользования Украины

\section{Миф как феномен культуры}

Цель исследования. Статья исследует миф как френомен культуры. Методология исследования. Авторы использовали антропологический интегративный подход, семиотический метод репрезентации мифа как языка культуры, а также феноменологический метод. Научная новизна. Мифы придают смысл и цель всем элементам культуры. Миф лежит в основе культурной реальности - он является ядром культуры. Если мы представим себе культуру как луковицу, состоящую из различных слоев (the "onion" model of culture), то миф будет еe центром - это сердцевина, которая вне артикуляции. Миф порождает наши убеждения и предположения, которые редко проявляются, однако именно они фоорируют как структуру нашей личности, так и культуру. Они считаются само собой разумеющимися и поддерживают любую культуру. Они проявляются в явном виде в ценностях, целях, стратегиях, философиях, которые мотивируют нас и фоормируют нашу реальность. Выводы. Мифология является одним из способов осмысления и интерпретации окружающего мира. Ее основные понятия - это «мир» и «человек». С помощью этих понятий люди осознавали свое предназначение в мире и формировали жизненные установки на ранних этапах человеческого развития. Уступив место философии и науке, мифология не утратила своего важного места в человеческой истории. Мифологические нарративы были заимствованы и многими религиями. В последние десятилетия представители литературы и искусства осознанно используют мифы для выражения своих идей. В своих произведениях они не только переосмысливают древние мифы, но и создают новые мифологические символы. В наше время интерес к мифу растет, и вряд ли это случайно. Знаменитые исследователи первобытной культуры и мифологии как способа освоения и интерпретации мира демонстрируют творческую силу и эвристический потенциал мифа, которые проявятся в будущем.

Ключевые слова: миф; мифология; мировоззрение; человек; мир; природа; сакральное время; профанное время; философия; наука.

Introduction. One of the distinctive characteristics of the postmodern world is the synthesis of different symbolic forms of culture, incompatible modes of thinking and types of worldview that interact both at individual and collective levels of consciousness. According to M. Maffesoli, "we could say that we are witnessing a return to syncretism in our society, which could be the melding of astrology, American New Age, pseudoscience in its many forms... Our century will see many of these somewhat mystical or esoteric forms returning" [18]. One of the major symbolic forms of culture is myth. Being a complex ambivalent structure, myth demonstrates the stability of its elements; it exists and develops within the current social cultural situation and permeates all spheres of human activity.

Encyclopaedia Britannica defines myth as "a symbolic narrative, usually of unknown origin and at least partly traditional, that ostensibly relates actual events and that is especially associated with religious belief. It is distinguished from symbolic behavior (cult, ritual) and symbolic places or objects (temples, icons). Myths are specific accounts of gods or superhuman beings involved in extraordinary events or circumstances in a time that is unspecified but which is understood as existing apart from ordinary human experience" [7]. The term mythology means both the study of the mythological narratives themselves and their deep meanings associated with a particular religious tradition. During the early stages of social development, mythology was the only way to understand and interpret natural and social realities. Being the first historical type of worldview, mythology embraced all forms of social consciousness - religion, art, science, morals, etc. Diffuse content of mythology displayed specific features of prehistoric humans. Not a separate human, but a group of them, their collective was a kind of social atom, which together with others shaped and developed human society. Contemporary interest in the theoretical interpretation of myths is far from accidental. As social practice shows, the symbolic and mythological forms of mastering reality play a huge role in creating our worldviews $[9 ; 10 ; 14 ; 24]$.

Literature review. A significant contribution to the study of myths has been made by romantics and $F$. Schelling, who interpreted myths as a form of humans' being. Key points and ideas for understanding the phenomenon of myth were developed by Z. Freud, C. Jung, E. Cassirer. They related myth to latent structures of human consciousness (Z. Freud, C. Jung) or interpreted it as a symbolic form (E. Cassirer). The peculiarities of mythological thinking were studied by J. Frazer, L. Levi-Bruhl, E. Durkheim, B. Malinowski and other researchers, who investigated primitive cultures. C. Levi-Strauss defined myth as an objectively existing structure in culture and described the logic of myths. According to M. Eliade, myth is a flexible structure that adapts to the new cultural forms. A. Losev, F. Kessidi, Ya. Golosovker, E. Meletinsky contributed greatly to a new level of understanding of myth - myth in the $20^{\text {th }}$ century "has become one of the central concepts in sociology and theory of culture" $[4,29]$.

The purpose of the study. This paper aims at exploring myth as a phenomenon of culture. 
Methodology of the study. The authors have used anthropological integrative approach, semiotic method of representing myth as a language of culture, as well as phenomenological method.

Theoretical basis and results. Incorporation of the cultural patterns in myths contributes to the formation of the cultural space within the more general field of social space and allows the representatives of a given culture to understand the diverse contexts of their own life experience [5; 19;23]. Myth as a narrative act is a set of rules that includes commonly agreed and successfully operated patterns within any given culture. It is an open and flexible model of the world and a model of the individual "l", by means of which people construct themselves as a part of their own world $[6 ; 9 ; 10]$. Myth reflects the perception of the world that is always full of interesting and surprising stories. Perception of the world in the mythological form is inherent in the very specifics of human thinking.

As A. Losev emphasizes, myth is not a fiction, fairy tale, but it is a category of our being and consciousness that has its own strict structure and logic [2]. Mythology appears to be a common cultural background, on which a magnificent temple of human thought arises. Indeed, mythology is the primary cultural factor, the very core of culture. For example, the Greek worldview of the Homeric era, its morality, law and art has a mythological background. Exploring world of mythologies, we come to the conclusion that myth is a spiritual and practical way of mastering reality. Myth does not reflect any kind of relation to nature and society, but only valuable for the whole society (clan/tribe). Mythology acts as a means of spiritual interpretation and transformation of the entire world order.

Myths are generalized images of a symbolic nature that include not only the existing world, but also the desired world, the world of hope, in which the key interests of the tribal group are embodied. Mythology is largely focused on overcoming the fundamental antinomies of human existence, on the harmonization of "human - nature - society" system. Myths are the first attempt to explain the principles of the universe. The archaic consciousness perceives any object not as equal to itself, but as a part of the other objects.

The French philosopher, anthropologist and ethnologist L. Levy-Bruhl sought to disclose the nature of consciousness of people, who were (as commonly believed) at a low level of social historical development. L. Levy-Bruhl came to the conclusion about the fundamental difference between primitive thinking (he attributed primitive thinking to culture) and the so-called civilized people's thinking [15]. Primitive thinking is both mystical and prelogical. It is guided by the law of participation; and associations play the main role. "By 'mystical', Levy-Bruhl means that 'primitive' peoples' experience the world as identical with themselves rather than, like moderns, as distinct from themselves. 'Primitive' peoples do not merely conceive but also perceive, or experience, the world as one with themselves. Their relationship to the world, including that to fellow human beings, is one of participation mystique. By 'prelogical', Levy-Bruhl means that 'primitives' are indifferent to contradictions rather than, like moderns, attentive to them. The 'primitive' mind deems all things identical with one another yet somehow still distinct - a logical contradiction. A human is simultaneously a tree and still a human being" $[21,636]$. L. Levy-Bruhl emphasizes that in a vast number of cases primitive thinking differs from ours. While we seek stable precedents, secondary causes that we consider to be real, primitive thinking is focused on mystical causes that are everywhere. Primitive thinking easily tolerates that the same being can stay in two or more places at the same time. It reveals complete indifference to the contradictions that our mind does not tolerate. Comparing this kind of thinking to ours, L. Levy-Bruhl coined it as primitive thinking. He stresses that this way of thinking is inherent in both primitive and modern mentality. In fact, there is no insurmountable boundary between prelogical and logical thinking; they can co-exist in one society and even within one consciousness. In the process of social development, logical thinking "pushes back" prelogical, however there will always be collective representations, which transmit such participation mystique to subsequent generations. They do not depend on the individual; they can not be comprehended and understood by examining an individual per se [15].

Human life within the framework of the mythological interpretive paradigm does not have clear space-time boundaries; it is woven into a seamless fabric of nature. Nature is not an external world, because a person does not separate him/herself from it. Within the mythological worldview, there are no stone fences between natural and supernatural worlds, since gods and people interact with each other. Thus, in myths the subject does not oppose him/herself to the object.

Mythology is characterized by splitting of primordial, mythical, sacred time and present, profane time. Mythological events are far away from the present time. They personify not just the past, but a special form of creation, the first things that precede the present. Everything that happens in sacred time acquires special significance and turns into paradigm and precedent. Thus, modeling is transformed into a specific function of myth. Myth exists in two aspects: diachronic (narrative about the past) and synchronic (interpretation of the present and/or the future). Within primitive mentality, myths are not fantastic stories; on the contrary, they are reality itself that includes the collective experience acquired by many generations. It is a matter of faith, not a criticism. Myths introduce a certain system of values and social norms. A. Losev and Ya. Golosovker support the idea that myth in its original form is not just a story, but the reality in which people live [1; 2]. According to A. Losev, myth is "life itself. For a mythical subject, this is a true life with all its hopes and fears, expectations and despair, with all its real everyday life and self-interest. Myth is not an ideal being, but a vital ... bodily reality" $[2,23]$. 
According to F. Nietzsche, every culture loses its healthy creative nature without myth - only myth makes culture complete [20]. E. Cassirer identifies myth with the spiritual culture [8]. B. Malinowski interprets myth as an integral part of culture, as something that is born again and again [17]. Myths still remain a mystery. The legacy of traditional cultures is persistently manifested in all subsequent cultures, either in artistic texts or in the collective consciousness or unconscious [11]. Deeply investigating the collective unconscious, C.G. Jung comes to the conclusion that the great myths awake in modern humans the awareness that they are facing with the universal phenomenon that can be compared to Nature itself. True mythology belongs to the spiritual reality [13].

Mythological consciousness formulates deep philosophical questions: what is our world; what is it to be a human; how did we get here; what is our final destination; what is nature; etc.? Philosophy, which took on a responsible task to answer these questions, arose in the depths of mythology. The first ancient Greek philosophical school was the Milesian school represented by Thales, Anaximander, and Anaximenes. For the first time in the known history, these philosophers deliberately raised the question on the fundamental principle of the world's being. Still basing on mythological ideas, they tried to explain the world order using the concept of four elements. The ancient philosophers began to rethink rationally the mythological material. This entailed the new question on the relationship between rational knowledge and mythological representations. The Sophists interpreted myths allegorically. For Plato, the doctrine of the universal living being became transcendental-dialectical basis of all mythology [3; 22] Allegorical interpretation of myths was represented by Stoics, Epicureans, and even Neo-Platonists, who compared myths with logical categories. Eventually philosophical and scientific worldviews were formed: the world around humans and humans themselves in the framework of the world were subjected to theoretical research and critical analysis. Sensual and imaginative relation to reality was replaced by logically harmonious system of knowledge. Certainly, the artistic perception of the world and imaginative thinking were preserved in the new types of worldview, however, intellectual rigor, logic of evidence, and a high level of abstraction were brought to the fore.

Many functions and implications have been attributed to myth. "They are often highly valued or disputed stories that still intrigue us even though many of us do not recognize them as a living genre in our culture... In fact, the contemporary connotation of myth as "a falsehood", often understood as being in opposition to science, probably stems from recognition of this attribute of myth... in isolation. Myths also seem in opposition to science because they are not testable, which is the case (at least for origin myths) because of their primordial setting - if events described are from a different, earlier world, then of course they would not be repeatable or logical in our world. Both myths and science offer explanations of the cosmos. A key difference is that information about the universe presented in myths is not testable, whereas science is designed to be tested repeatedly. Science also depends on cumulative, frequently updated knowledge, whereas myth is based on passed down stories and beliefs. Myths may change over time, particularly after contact with other cultures, but they do not change and adapt to new periods and technological developments in the same way science does. Myths may be enacted through rituals and believed in absolutely, but they usually do not have physical effects in the real world, as in leading to new technology for building cars or providing medical treatment. People may believe they are cured through faith, and they may find important value-laden sentiments in myths, but these "real world results" are neither empirical nor usually repeatable (two standard criteria for science). Although science differs from myth in offering actual, testable control over the environment and producing real, repeatable results in the world, science is NOT completely divorced from myth. Many scientific theories are presented or understood in narrative form, which often end up sounding remarkably mythic..." [16].

The scientific novelty. Myths provide meaning and purpose to all elements of culture. Myth underlies cultural reality - it is a core of culture. If we imagine culture as an onion comprised of different layers (the "onion" model of culture) [12], then myth is the center of it - it is a core beyond articulation. It generates our beliefs and assumptions that are rarely explicated, however these beliefs and assumptions shape both the structure of personality and culture. They are taken for granted, but support any culture. They manifest themselves in an explicit form in values, purposes, goals, strategies and philosophies, which motivate us and shape our reality.

Conclusions. Mythology is one of the ways to comprehend and interpret the world around us. Its basic concepts are the "world" and "human". Through the lens of these concepts, people realized their destiny in the world and formed life attitudes during the early stages of human development. Giving place to philosophy and science, mythology has not lost its important place in human history. Mythological narratives were borrowed by many religions. In recent decades, representatives of literature and art have intentionally used myths to express their ideas. They have not only rethought ancient myths, but have created new mythological symbols. Nowadays, an interest in myths and mythologies has dramatically increased, and it is not by chance. The famous researchers of the primitive cultures and mythologies as the ways of mastering and interpreting the world have demonstrated the creative power and heuristic potential of myths that will be manifested in the future.

\section{תimepamypa}

1. Голосовкер Я.Э. Избранное. Логика мифа. М.; СПб.: Центр гуманитарных инициатив, 2010. 499 с. 
2. Лосев А.Ф. Диалектика мифра. М.: Академический проект, 2008. 304 с.

3. Лосев А. Ф. История античной эстетики. Софисты. Сократ. Платон. М.: Фолио; АСТ, 2000. 848 с.

4. Мелетинский Е.М. Поэтика мифа. М.: Наука, 1976. 407 с.

5. Шинкарук В.Д., Салата Г.В., Данилова Т.В. Дихотомія «культура - цивілізація» в англоамериканському і західноєвропейському науковому дискурсі. Вісник Національної академії керівних кадрів культури і мистецтв. 2018. №2. С. 82-87.

6. Brockmeier J. Narrative: Problems and promises of an alternative paradigm. Narrative and Identity: Studies in autobiography, self and culture / J. Brockmeier \& D. Carbaugh (Eds). Amsterdam \&Philadelphia: John Benjamins, 2001. PP. 39-58.

7. Buxton R.G.A., Bolle K.W., Smith J.Z. Myth. Encyclopaedia Britannica. 2017. Retrieved from http://www.britannica.com/topic/myth.

8. Cassirer E. The Philosophy of Symbolic Forms. Yale University Press. 1953. 237 p.

9. Danylova T.V. Eastern Mysticism and Timothy Leary: Human Beyond the Conventional Reality. Anthropological Measurements of Philosophical Research. 2017. Is.11. P. 135-142. DOI: 10.15802/ampr.v0i11.105498.

10. Danylova T.V. Searching for the True Self: The Way of Nondual Wisdom. Anthropological Measurements of Philosophical Research. 2017. Is.12. P. 7-15. Doi 10.15802/ampr.v0i12.119069.

11. Danylova T.V. The Way to the Self: The Novel "Steppenwolf" Through the Lens of Jungian Process of Individuation. Anthropological Measurements of Philosophical Research. 2015. Is. 7. P. 28-35.

12. Hofstede's Cultural Onion. Notes on Intercultural Communication. 2013. Retrieved from https://laofutze.wordpress.com/2009/08/28/303/

13. Jung K.G., Kerenyi C. Essays on a Science of Mythology. Princeton University Press. 1969. 208 p.

14. Khmil V., Malivskyi A. Contemporary Reception of Rene Descartes' Skepticism. Philosophy and Cosmology. 2017. Is. 19, P. 168-178.

15. Levy-Bruhl L. Primitive Mentality. Forgotten Books, 2018. 470 p.

16. Magoulick M. What is Myth? Folklore Connections. 2015. Retrieved from https://faculty.gcsu.edu/customwebsite/mary-magoulick/defmyth.htm

17. Malinowski B. Magic, Science and Religion. Martino Fine Books, 2015. 92 p.

18. Maffesoli M. Interview with Michel Maffesoli. Mètode. Universitat de València. 2013. Retrieved from https://metode.org/issues/entrevista-revistes/michel-maffesoli-2.html

19. McCalman I. Cultural History and Cultural Studies: the linguistic turn five years on. (Undated). Retrieved from http://www.nla.gov.au/events/history/papers/lain_McCalman.html

20. Nietzsche F. The Birth of Tragedy or Hellenism and Pessimism. CreateSpace Independent Publishing Platform, 2016. $176 \mathrm{p}$.

21. Segal R.A. Jung and Levy-Bruhl. Journal of Analytical Psychology. 2007. Vol. 52. Is. 5. P. 635-658.

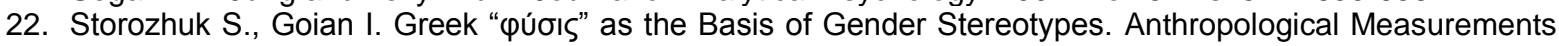
of Philosophical Research. 2016. Is. 10. P. 78-89. DOI: 10.15802/ampr.v0i10.87306

23. Storozhuk S., Goian I. Gender Existence: Correlation Between Equality and Identity. Philosophy and Cosmology. 2017. Vol. 18. P. 208-218.

24. Vus V., Kychkyruk T., Lokutova E. Social and Personal Development of Preschoolers Through The Lens of Parental Religious Educational Models. Science and Education. 2018. Is. 1. P. 60-64. DOI: https://doi.org/10.24195/2414-4665-2018-1-8

\section{References}

1. Golosovker, Ya.E. (2010). Selected works. The logic of myth. Moscow; Saint Petersburg: Center for Humanitarian Initiatives [in Russian].

2. Losev, A.F. (2008). Dialectics of myth. Moscow: Academic project [in Russian].

[in Russian].

3. Losev, A.F. (2000). The history of ancient aesthetics. The Sophists. Socrates. Plato. Moscow: Folio; AST

4. Meletinsky, Ye.M. Poetics of myth. Moscow: Nauka [in Russian].

5. Shynkaruk, V.D., Salata, G.V., \& Danylova, T.V. (2018). The Dichotomy "Culture - Civilization" in the Anglo-American and Western European Scientific Discourse. National Academy of Managerial Staff of Culture and Arts Herald, 2, 82-87 [in Ukrainian].

6. Brockmeier, J. (2001). Narrative: Problems and promises of an alternative paradigm. Narrative and Identity: Studies in autobiography, self and culture / J. Brockmeier \& D. Carbaugh (Eds). Amsterdam \&Philadelphia: John Benjamins.

7. Buxton, R.G.A., Bolle, K.W., \& Smith, J.Z. (2017). Myth. Encyclopaedia Britannica. Retrieved from http://www.britannica.com/topic/myth.

8. Cassirer, E. (1953). The Philosophy of Symbolic Forms. Yale University Press.

9. Danylova, T.V. (2017). Eastern Mysticism and Timothy Leary: Human Beyond the Conventional Reality. Anthropological Measurements of Philosophical Research, 11, 135-142. DOI: 10.15802/ampr.v0i11.105498.

10. Danylova, T.V. (2017). Searching for the True Self: The Way of Nondual Wisdom. Anthropological Measurements of Philosophical Research, 12, 7-15. Doi 10.15802/ampr.v0i12.119069.

11. Danylova, T.V. (2015). The Way to the Self: The Novel "Steppenwolf" Through the Lens of Jungian Process of Individuation. Anthropological Measurements of Philosophical Research, 7, 28-35.

12. Hofstede's Cultural Onion. Notes on Intercultural Communication. 2013. Retrieved from https://laofutze.wordpress.com/2009/08/28/303/

13. Jung, K.G., \& Kerenyi, C. (1969). Essays on a Science of Mythology. Princeton University Press.

14. Khmil, V., \& Malivskyi, A. (2017). Contemporary Reception of Rene Descartes' Skepticism. Philosophy and Cosmology, 19, 168-178.

15. Levy-Bruhl, L. (2018). Primitive Mentality. Forgotten Books. 
16. Magoulick, M. (2015). What is Myth? Folklore Connections. Retrieved from https://faculty.gcsu.edu/customwebsite/mary-magoulick/defmyth.htm

17. Malinowski, B. (2015). Magic, Science and Religion. Martino Fine Books.

18. Maffesoli, M. (2013). Interview with Michel Maffesoli. Mètode. Universitat de València. Retrieved from https://metode.org/issues/entrevista-revistes/michel-maffesoli-2.html

19. McCalman, I. (Undated). Cultural History and Cultural Studies: the linguistic turn five years on. Retrieved from http://www.nla.gov.au/events/history/papers/lain_McCalman.html

20. Nietzsche, F. (2016). The Birth of Tragedy or Hellenism and Pessimism. CreateSpace Independent Publishing Platform.

21. Segal, R.A. (2007). Jung and Levy-Bruhl. Journal of Analytical Psychology, 52(5), 635-658.

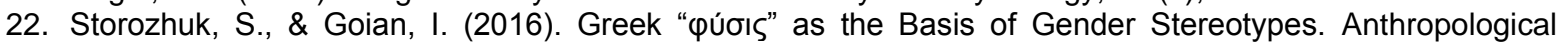
Measurements of Philosophical Research, 10, 78-89. DOI: 10.15802/ampr.v0i10.87306

23. Storozhuk, S., Goian, I. Gender Existence: Correlation Between Equality and Identity. Philosophy and Cosmology. 2017. Vol. 18. P. 208-218.

24. Vus V., Kychkyruk T., \& Lokutova E. (2018). Social and Personal Development of Preschoolers Through The Lens of Parental Religious Educational Models. Science and Education, 1, 60-64. DOI: https://doi.org/10.24195/2414-4665-2018-1-8

Стаття надійшла до редакції 13.10.2018 p.

UDC $1: 316.3+340.12$

\author{
Tatsiy Vasyl \\ Doctor of Legal Sciences, Professor, \\ Rector of Yaroslav Mudryi \\ National Law University

\title{
THE RULE OF LAW: MODERN SCIENTIFIC DISCOURSE AND PRACTICAL REALIZATION IN UKRAINE
}

The purpose of the article is to investigate in theoretical and practical aspects of the peculiarities of the formation of the rule of law in modern Ukraine. The methodology is based on a complex combination of general scientific (analysis, synthesis, analogy, etc.), philosophical (dialectical, hermeneutical) and special legal (regulatory and analytical, comparative legal) methods. The scientific novelty of the work lies in the systemic disclosure of institutional and noninstitutional factors for the development of the rule of law in Ukraine, highlighting the problematic issues that arise at the present stage of national state-building. Conclusions. The scientific discourse about the features of the realization of the essential features of the rule of law in modern Ukraine unfolds in the following areas - ensuring quality of judicial and law enforcement activities, clear separation of powers between the branches of government and its structures (in order to avoid duplication, dual subordination), raising the level of legislative work in the Ukrainian Parliament, adherence to the principles of the rule of law in all areas of public life no and so on. Generally, it can be stated that in modern Ukraine the rule of law is only being born, and the compliance with the principles of its functioning in domestic legal relations is not yet systemic. The development of the institutions of the rule of law is an integral part of the entire political system in the country. That is why there is a need to reform the judicial branch of the government, law enforcement agencies, lawmaking procedures, taking into account the best foreign examples. One of the ways to improve the quality of legislative work is the creation of bicameral parliament in Ukraine, which should ensure more thorough consideration of the draft laws, representation of the regions, and which will serve as a forum for finding a compromise on the strategic directions of the country's development. As the experience of the countries with stable democratic traditions shows, for the development of the rule of law, it is not enough to adopt quality laws; important is their perception and implementation by all subjects of social relations, which have a developed legal awareness and legal culture of democratic quality. To raise the level of legal recognition and legal culture of Ukrainian citizens, we propose to create a system of legal education and upbringing that would be supported by the state and civil society. To ensure legal education and upbringing legal policy of the country, a number of consecutive steps should be foreseen.

Key words: the rule of law state; human rights; bicameralism; legal education and upbringing; principles of lawmaking; the rule of law; legal culture.

(C) Tatsiy V., 2018

(C) Danilian O., 2018 